\title{
Změny sebepojetí klientů terapeutických komunit pro drogově závislé prostřednictvím terapie dobrodružstvím
}

\author{
Anna Šlachtová, ${ }^{\mathrm{a}}$ \\ Bohdana Richterová, \\ Ivo Müller ${ }^{\mathrm{C}}$
}

$\triangle$ Correspondence: bohdana.richterova@osu.cz

Copyright (C) 2019 by the author and publisher, TBU in Zlín. This work is licensed under the Creative Commons Attribution International License (CC BY).

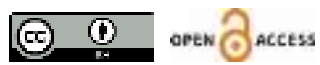

\begin{abstract}
Abstrakt: Programy terapie dobrodružstvím patři mezi jeden $z$ prostředků práce $s$ klienty $v$ terapeutických komunitách pro drogově závislé. Příspěvek představuje dílči výsledky empirické části studentského grantového projektu. Cílem je na základě kvantitativního výzkumu zjistit, zda dochází ke změnám sebepojetí u klientů šesti terapeutických komunit pro drogově závislé $v$ České republice $v$ rámci terapie dobrodružstvím. Výzkumné šetření je realizováno dotazníkovou metodou ve 3 etapách: před programem, po jeho uskutečnění a znovu po čtrnácti dnech po absolvování terapie dobrodružstvím. Výzkumný vzorek je tvořen sto klienty vybraných terapeutických komunit. Výsledky Friedmanova testu ukazují statisticky významné změny v oblasti self-efficacy, ve vnímání fyzické kondice a sportovních kompetencí. Tyto výsledky ukazují na smysluplnost zařazování programů do práce s klienty v terapeutických komunitách.
\end{abstract}

Klíčová slova: terapie dobrodružstvím, zátěžové aktivity, terapeutická komunita, sebepojetí, sebeúcta, self-efficacy

\section{Changes in clients'self-concept during adventure therapy in therapeutic communities for drug addicts}

\begin{abstract}
Programs of adventure therapy are among the tools for working with clients in therapeutic communities for drug addicts. The paper presents partial results of the empirical part of the students' grant project. The goal is to find a quantitative foundation for the research, and whether there are changes in clients' self-concept within the adventure therapy in six therapeutic communities for drug addicts in the Czech Republic. The research was carried out using the questionnaire method in three phases: before the program, after its completation and fourteen days after. The research sample is created by a hundred clients from chosen therapeutic communities. The outcomes of the Friedman test shows statistically significant changes in the field of self-efficacy and in the perception of physical condition and sport competences. These results point to the meaningfulness of putting these programs to working with clients in therapeutic communities.
\end{abstract}

Keywords: adventure therapy, activities with physical and mental strain, therapeutic community, self-concept, selfesteem, self-efficacy 


\section{1 Úvod}

Pobyt $v$ terapeutické komunitě je jednou z možností, kterou si může vybrat člověk se závislostí mající zájem o změnu svého současného života. První komunita vznikla v České republice již na počátku 90. let (Radimecký, 2006) a od té doby se jejich počet rozrostl na desítku dalších, zř́zených bud' psychiatrickými nemocnicemi ve zdravotnictví, nebo jako sociální služby. Postupně se terapeutické komunity staly významnou součástí celkového systému péče o drogově závislé (Doležalová, 2006). Nabízí strukturovaný léčebný program v podmínkách malé skupiny, kde je konečným cílem schopnost postupné resocializace a znovuzačlenění do většinové společnosti. Klient $v$ terapeutické komunitě prochází několika fázemi, které na sebe postupně navazují. Některé prostředky léčby využívají všechny terapeutické skupiny (např. komunitní setkání, pracovní terapie, přebírání praktických rolí v komunitě, práce s rituály a další), jiné využívají pouze některé. Mezi ně patří např́iklad programy terapie dobrodružstvím (angl. adventure therapy nebo wilderness therapy) v praxi lidově nazývanými zátěžovými aktivitami, na které se zaměřil náš výzkum.

$\checkmark$ diskuzích pracovníků terapeutických komunit jsme zaznamenali rozdílné pohledy na to, zda je vhodné tuto metodu do programu zařazovat, či ne. Největšími argumenty proti byly časová náročnost na prípravu a realizaci aktivit, vysoké riziko nebezpečí úrazu, záporný vztah některých klientů k podobným druhům aktivit, vysoké nároky na fyzickou a psychickou odolnost pracovníků terapeutických komunit, uměle navozovaný stres a nejistý účinek aktivit. Pracovníci, kteří aktivity obhajovali jako důležitou součást léčby, popisovali vnímané zvýšení soudržnosti skupiny, posílení vztahu pracovník-terapeut, pozitivní dopady překonání vlastních fyzických limitů, vznik témat pro navazující terapeutickou práci a radost a uspokojení ze zvládnutí těchto akcí nejen klienty, ale také pracovníky. $V$ českém prostředí jsme objevili pouze dva výzkumy věnující se tomuto tématu, a to výzkum Romaněnkové (2012) analyzující názory pracovníků na tyto aktivity a Richterové, Štenclové a Červenkové (2017), specifický výzkum - projekt studentské grantové soutěže Ostravské univerzity, který se v letech 2015-2016 zaměřil na analyzování názorů klientů jedné vybrané terapeutické komunity na tyto aktivity. Ani jeden z těchto výzkumů nepoužil standardizované metody a pro svůj omezený počet respondentů neumožnil z daných zjištění provádět generalizace. Naopak řada výzkumů zabývajících se účinky této metody byla objevena v zahraničí. Programy terapie dobrodružstvími byly realizovány ve skupinách lidí se závislostmi a delikventním chováním, bohužel ani jeden publikovaný výzkum se nezaměřil na použití programu v terapeutické komunitě.

Tento příspěvek představuje dílči výsledky empirické části projektu studentské grantové soutěže, který navázal svým tématem na předchozí analýzu názorů klientů. Již využil standardizovaných metod a do výzkumu se zapojili klienti šesti terapeutických komunit v České republice, které zařazují terapii dobrodružstvím do svých programů.

Cílem empirické části projektu je na základě kvantitativního výzkumu zjistit, k jakým změnám v sebepojetí dochází u klientů šesti terapeutických komunit pro drogově závislé v České republice při zařazení programů terapie dobrodružstvím. Následující text předkládá teoretický kontext výzkumu, seznámení s cílem a metodami výzkumu, výzkumným vzorkem, představuje hlavní výsledky výzkumu a návrhy na úpravy klíčových výzkumných metod pro druhý rok realizace výzkumu.

\section{Sebepojetí drogově závislých a terapie dobrodružstvím}

Sebepojetí hraje významnou roli v úspěšné léčbě drogové závislosti. Sebepojetí klientů terapeutických komunit je však jedním ze čtyř nejčastějších problémů v léčbě (Kalina, 2008). V rámci léčby je nezbytné překonat zranitelnost a deficit zejména $v$ oblasti péče o sebe, seberegulace a sebeúcty. Hlavním cílem terapeutické komunity je pomoci klientům abstinovat od látky, na kterou se jim vytvořila závislost. Podstatná je také změna životního stylu závislých, která nejčastěji probíhá prostřednictvím osobního růstu, změny sebepojetí, některých postojů a chování (Kalina a kol., 2015). 
Sebepojetí a sebeúcta jsou u většiny klientů na nízké úrovni (resp. nepřiměřené), klienti se často potýkají s vnitřními pocity méněcennosti, nedostatkem sebeúcty, nízkou sebedůvěrou. Taktéž v oblasti tělesného sebepojetí, které je součástí celkového sebepojetí, se u drogově závislých ukazují negativní postoje vůči vlastní osobě. Objevuje se nízké vědomí totožnosti s vlastním tělem, necitlivost $k$ vlastním emocím, či dokonce odtrženost od vlastního těla (Kalina, 2008).

Na počátku léčby bývají někteří klienti pasivní a staví se do role oběti. Během léčby se učí změnit dosavadní způsob života a postoj vůči sobě samému, osamostatnit se, převzít odpovědnost za sebe a své chování. Bandurův koncept „self-efficacy“ vztahující se k pocitu vlastní účinnosti, schopnosti řídit a kontrolovat svůj život (Bandura, 1994) Ize spatřovat v léčebném procesu terapeutické komunity. Klienti se postupně přestávají zasazovat do role oběti vnějších vlivů, začínají sebe sama vnímat jako schopného a aktivního činitele a tvưrce svého osudu (Rečková, 2010). Koncept je využíván také v prevenci relapsu jako jedna ze zásadních teorií. Podle Kudy (Kalina a kol., 2015) si klient stanovuje vlastní pravidla a cíle, kterých chce dosáhnout. Pokud se mu to daří, zažívá pocit vlastní účinnosti a je schopen se $v$ budoucnu snáze vyrovnat s rizikovými situacemi.

Ukazuje se, že dobrodružné aktivity poskytující mimořádné a intenzivní prožitky mají vysoký potenciál ovlivňovat osobnost jedince a přispívat $k$ jeho osobnostnímu rozvoji (Fleischer, Doebler, Bürkner, \& Holling, 2017; Chytilová, 2005; Kirchner, 2009; Kirchner \& Hátlová, 2011; Lebeda, 2006; Mutz \& Müller, 2016 aj.). Dokonce se objevují názory, že aplikování dobrodružných aktivit s intenzivními prožitky v léčbě závislostí může působit jako prostředek k potlačení stavů bažení (Kirchner, 2009).

Dobrodružné aktivity, často realizované $v$ př́rodním a odlehlém prostředí, jsou základním terapeutickým prostředkem terapie dobrodružstvím (Gass, Gillis, \& Russell, 2012). Rataj (2007) ve smyslu terapie dobrodružstvím hovoří o zátěžových programech či zátěžové terapii jako o tradičním programu terapeutických komunit, který se významně podílí na procesu integrace a resocializace klienta. Bývá realizován formou několikadenních výprav sportovně-turisticko-poznávacího charakteru a obsahuje určitou míru fyzické a psychické zátěže a náročnosti. Tyto programy zvyšují kondici, poskytují možnost ověřit si vlastní limity, zážitek sebepřekonání má pozitivní vliv na sebedůvěru a sebeúctu, schopnost rozvrhnout síly, být samostatný a nezávislý, pěstovat vůli a sebezapření.

\section{Výzkumný problém a cíl výzkumu}

V České republice Ize dohledat pouze málo odborných publikací a výzkumů zabývajících se zátěžovými aktivitami či terapií dobrodružstvím $v$ léčbě drogové závislosti. Výjimku tvoří texty o realizaci a prínosech těchto programů (Rataj, 2007), analýzy názorů pracovníků (Romaněnková, 2012) a klientů terapeutických komunit na tyto aktivity (Richterová, Štenclová, \& Červenková, 2017). Zcela chybí výzkumy, které by potvrzovaly (popř. vyvracely) účinek terapie dobrodružstvím, resp. vliv této metody na globální sebepojetí, tělesné sebepojetí a self-efficacy klientů terapeutických komunit. Zahraničních výzkumů k vybranému tématu je možné nalézt více. Mapující přehled Srovnala (2018) zaměřený na nejnovější kvantitativní výzkumy programů terapie dobrodružstvím objevil v zahraničí několik programů pro osoby s drogovou závislostí. Jejich zjištění se zabývají spiše vlivem programů na snížení užívání návykových látek než na rozdíly klientů v oblastech sebepojetí před a po realizaci programu (např. Lewis, 2012). Výzkum ve Velké Británii ověřil po ukončení programu terapie dobrodružstvím pro mladistvé s drogovou minulostí významné zlepšení v interpersonálních vztazích v rodině i ve škole, u dívek významné snížení myšlenek na sebevraždu a zlepšení prospěchu ve škole ( $\underline{\text { Harper, Russell, }}$ Cooley, \& Cupples, 2007).

Předložená studie se zaměřuje na zjištění „Jaký je vztah mezi sebepojetím klientů šesti terapeutických komunit pro drogově závislé v České republice a účastí na aktivitách terapie dobrodružstvím?“. Bylo stanoveno šest dílčích výzkumných otázek a hypotéz. 
Dílčí výzkumná otázka č. 1 zjištujue: K jakým statisticky významným změnám dochází v oblasti selfefficacy u klientů terapeutických komunit před, po a 14 dní po absolvování programu terapie dobrodružstvím?

Předpokládáme, že se hodnoty skórů self-efficacy u klientů terapeutických komunit budou před, po a 14 dní ${ }^{1}$ po absolvování programu terapie dobrodružstvím lišit. Zároveň předpokládáme, že hodnoty skórů self-efficacy budou po absolvování programu terapie dobrodružstvím vyšší než před jejím absolvováním. Tento předpoklad vychází z Rataje (2007, s. 168), který uvádí, že terapie dobrodružstvím má pozitivní vliv na sebedůvěru a sebeúctu. Během programu terapie dobrodružstvím je posilována schopnost rozvrhnout síly, být samostatný a nezávislý, pěstovat vưli a sebezapření. Klienti mohou pocítit zážitek sebepřekonání, které pozitivně ovlivňuje motivaci a vưli.

Podle Bandury (1994) Ize self-efficacy čerpat ze 4 zdrojů. Nejefektivnější je tzv. mastery experience - pozitivní autentická zkušenost. Úspěchy vytvářejí silné pocity vlastní účinnosti. Druhým zdrojem je zástupná zkušenost - prostřednictvím pozorování modelů, přičemž účinek je silně ovlivněn vnímanou podobností s modely. Třetím zdrojem je přesvědčování - podpora okolí a víra v schopnosti zvyšuje pravděpodobnost úspěchu. Posledním zdrojem je úsudek o vlastním fyziologickém stavu (Bandura, 1994; Janoušek, 1992). Všechny tyto zdroje jsou př́tomny při realizaci programů terapie dobrodružstvím.

Terapie dobrodružstvím je však součástí širší terapeutické práce a po jejím absolvování by mělo dojít ke zpracování a vyhodnocení akce s klienty (Gass et al., 2012; „Seznam“, 2017). Kirchner (2009, s. 107) uvádí, že rozdíl mezi rekreačními aktivitami a aktivitami s výchovným či terapeutickým charakterem tkví v reflexi. Reflexi je možno chápat jako druh sebepozorování, kdy obracíme myšlenky do sebe, do vlastního vědomí a prožitků a následně jsme schopni se z tohoto procesu učit (Hartl \& Hartlová, 2015). Reflexe programu terapie dobrodružstvím by měla proběhnout s odstupem: „Až s odstupem se dokážeme na aktivitu podívat nezaujatým pohledem, který již tak bezprostředně není ovlivněn emocemi z průběhu akce." Je možné, že se hodnoty skórů self-efficacy 14 dní po absolvování programu terapie dobrodružstvím budou vracet k původním hodnotám před absolvováním programu.

Dílčí výzkumné otázky č. 2-6 se vztahují k tělesnému sebepojetí. Zaměřují se jednak na změny obecné tělesné sebeúcty (TS) a jednak na změny dílčích prvků tělesné sebeúcty: sportovní kompetence (SPORT), tělesné atraktivity (TĚLO), fyzické síly (SíLA) a fyzické kondice (KOND).

Tělesné sebepojetí je pojem, kterým Ize označit názory o podobě, rozměrech a vlastnostech vlastního těla a zároveň emoce, které se $\mathrm{k}$ podobě, rozměrům a vlastnostem vlastního těla vztahují. Pro náš výzkum je podstatný následující fakt: tělesné sebepojetí je subjektivní, tzn. subjektivní vnímání a hodnocení vlastního těla nemusí odpovídat objektivní realitě. Zároveň je elastické, tzn. že může docházet ke změnám při sociální zkušenosti (Fischer \& Škoda, 2014).

Tomešová $(\underline{2005})$ tělesnou sebeúctu na doménové úrovni definuje jako obecné pocity štěstí, spokojenosti, hrdosti, respektu a jistoty $v$ tělesném sebepojetí. Hodnota této domény vyjadřuje celkovou spokojenost $s$ tělesným Já. Podle Foxe (Tomešová, 2005) tělesná sebeúcta i jiné části sebepojetí mohou být ovlivněny pohybovými aktivitami či tělesným cvičením, přičemž nejvýraznější pozitivní efekt je u osob s nízkou sebeúctou. Terapie dobrodružstvím má rekondiční zdravý sportovní charakter (Rataj, 2007), a proto může být účinnou metodou, jak zvyšovat tělesnou sebeúctu klientů.

Rataj $(2007$, s. 168) spatřuje pozitivní vliv terapie dobrodružstvím v různých oblastech, které se k tělesnému sebepojetí vztahují: „,klienti se po absolvování programu cítí pevnější, mají lepší kondici, mohou být inspirováni k sportovním činnostem ve volném čase," aktivity v rámci programu konfrontují

1 Realizování retestu 14 dní po konání programu bylo vybráno s ohledem na opakovanou měsíční frekvenci zařazování programů terapie dobrodružstvím ve dvou z vybraných terapeutických komunit. Přetrvávající účinek byl zjištován tedy pouze 14 dní po absolvování programu. 
klienty s jejich schopnostmi, účast na nich vyžaduje aktivní zapojení schopností, rozvijí psychomotoriku, pưsobí zejména na schopnost rozvrhnout síly.

Na základě výše uvedených poznatků byly zformulovány hypotézy vztahující se k dílčím výzkumným otázkám č. 2-6. Předpokládáme, že se hodnoty skórů budou před, po a 14 dní po absolvování programu terapie dobrodružstvím lišit, proto hypotézy uvádíme jako alternativní (př́slušné nulové hypotézy říkají, že se hodnoty skórů před, po a 14 dní po programu neliší). Na základě výše uvedených teoretických poznatků Fischera a Škody (2014), Tomešové (2005) a Rataje (2007) Ize předpokládat zvýšení hodnot skórů po absolvování programu terapie dobrodružstvím. Avšak stejně jako u výzkumné otázky č. 1 je potřeba zohlednit následující fakt: aktivity v rámci terapie dobrodružstvím jsou silným zážitkem a může tak docházet $\mathrm{k}$ prudkým výkyvům sebepojetí klientů. S odstupem Ize na aktivitu nahlížet "nezaujatým pohledem, který již tak bezprostředně není ovlivněn emocemi z průběhu akce" (Kirchner, 2009, s. 107). Hodnoty skórů mohou být po 14 dnech od absolvování programu terapie dobrodružstvím ovlivněny již zmiňovanou reflexí a může dojít k jejich poklesu.

\section{Výzkumný soubor}

Výzkumný vzorek tvoří klienti šesti terapeutických komunit v České republice, kteř́ se v průběhu své střednědobé či dlouhodobé léčby účastnili terapie dobrodružstvím. Účast ve výzkumu byla dobrovolná. S cílem a průběhem výzkumu byli podrobně seznámeni pověření pracovníci těchto komunit. Klienti byli informováni prostřednictvím informovaného souhlasu o cíli výzkumu, způsobu sběru dat a anonymitě. $\checkmark$ prípadě zájmu účastnit se dotazníkového šetření byl jimi tento dokument podepsán.

Celkem bylo do výzkumu zapojeno šest terapeutických komunit v České republice:

1. TK Fides - Bílá Voda,

2. TK Fénix - Bílá Voda,

3. TK Němčice $v$ Heřmani,
4. TK White Light I. v Mukařově,

5. TK Advaita v Nové Vsi u Liberce,

6. TK Magdaléna v Mnišku pod Brdy

Jednotkou výzkumu je výpověd' klienta ke konkrétnímu programu terapie dobrodružstvím zjištovaná dotazníky před aktivitou, po ní a 14 dní po účasti v programu. Tato informace znamená, že klient byl zařazen do výzkumu i vícekrát se sadou tří testování, pokud se během svého pobytu v terapeutické komunitě zúčastnil několika programů terapie dobrodružstvím. Celkem bylo do výzkumu zapojeno v roce 2017110 klientů, kteří se zúčastnili jednoho nebo více programů terapie dobrodružstvím. Z hlediska pohlaví se jednalo o 78 mužů (71 \%) a 31 žen (29 \%). Průměrný věk klientů byl okolo 31 let. Nejmladší zúčastněný klient byl ve věku 17 let a nejstarší ve věku 52 let. Z důvodů následujícího statistického zpracování dat bylo z dalšího zpracování nutné vyřadit 10 klientů, u nichž chyběl jeden ze tří dotazníků (tj. před, po, 14 dní po).

Tabulka 1 představuje charakteristiku výzkumného souboru. Celkem byla zpracována data od 100 klientů, kteří se zúčastnili jednoho nebo více TD. Z hlediska pohlaví se jednalo o 70 (70 \%) mužů a 30 (30 \%) žen. Průměrný věk klientů byl 30,9 let.

Tabulka 1

Charakteristika výzkumného souboru klientů TK v roce 2017

\begin{tabular}{lllll}
\hline Terapeutická komunita & Klienti $(\mathrm{N})$ & Muži $(\mathrm{N})$ & Ženy $(\mathrm{N})$ & Průměrný věk \\
\hline Advaita & 15 & 11 & 4 & 29,3 \\
Fénix & 14 & 11 & 3 & 31,4 \\
Fides & 32 & 23 & 9 & 28,9 \\
Magdaléna & 10 & 5 & 5 & 31,8 \\
Němčice & 17 & 14 & 3 & 35,8 \\
White Light I. & 12 & 6 & 6 & 29,8 \\
\hline Celkem & 100 & 70 & 30 & 30,9 \\
\hline
\end{tabular}




\section{Realizované programy terapie dobrodružstvím}

V každé z výše uvedených komunit probíhá terapie dobrodružstvím. Do výzkumu byly zařazeny pouze ty akce, které splňují základní definiční vymezení terapie dobrodružstvím: „Zátěžové aktivity (terapie dobrodružstvím) jakožto součást léčebného procesu jsou psychicky a fyzicky náročné činnosti uskutečňující se formou několikadenních výprav sportovně-turisticko-poznávacího charakteru“ (Richterová a kol., 2015, s. 94). Do aktivit byly zařazeny pouze takové, které trvaly dvě a více nocí mimo terapeutickou komunitu.

Do testování byli zapojeni pouze ti klienti, kteří absolvovali terapii dobrodružstvím v jejím plném rozsahu. Celkem bylo do výzkumu zařazeno 15 programů terapie dobrodružstvím. Z testování byly vyřazeny akce, které nesplňovaly definiční vymezení terapie dobrodružstvím (např. jednodenní akce, doprava na místo akce vlakem, kulturní akce). Taktéž bylo u jedné terapeutické komunity nutno vyřadit akci, jejiž testování by se krylo s testováním akce předcházející. Počty realizovaných programů terapie dobrodružstvím, které byly zařazeny do výzkumného šetření, konkretizuje graf 1.

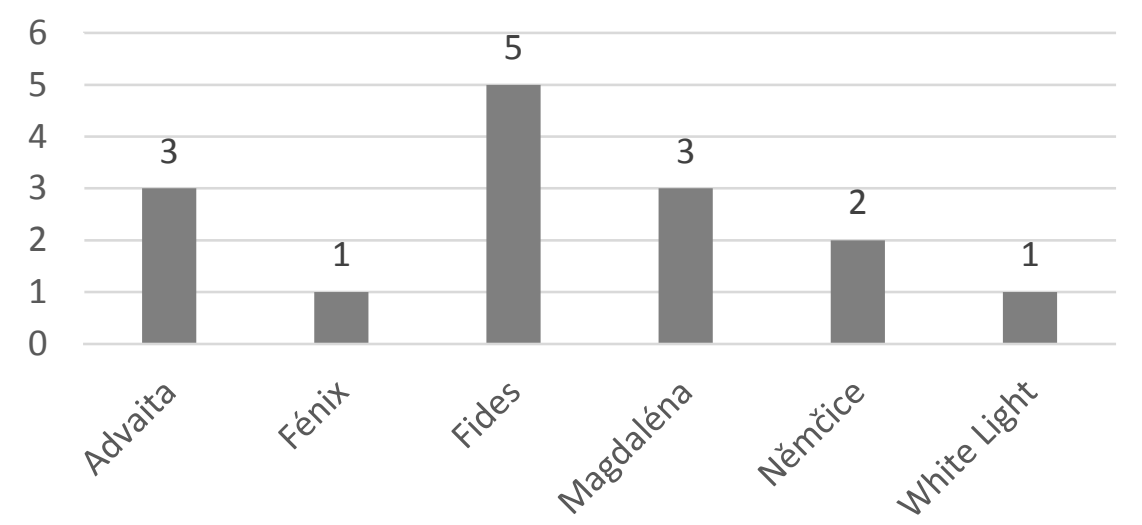

Graf 1 Počet programů terapie dobrodružstvím zařazených do výzkumného šetření dle terapeutických komunit

Tabulka 2 představuje základní charakteristiky programů, které byly zařazeny do výzkumu v roce 2017. V zimním období (únor/březen 2017) probíhaly nejčastěji akce typu stanování na sněhu a běžkování v kombinaci s turistikou. Nejvíce akcí probíhalo v období jaro/léto (duben, květen, červen, červenec, srpen 2017). Jednalo se především o turistické akce v podobě několika kilometrových pochodů. Dále proběhly cyklistické akce, vodácká akce a akce zaměřená na horolezectví. Poslední akce, která byla do výzkumného šetření zahrnuta, probíhala v období zářířijen 2017. Každý z programů připravuje tým dvou až tří pracovníků terapeutické komunity a vybraných klientů, kteří se aktivity poté také účastní. Cílem programů je, aby všichni zúčastnění zažili v rámci programu zátěžové situace a vrátili se zpět do terapeutické komunity s novými zkušenostmi, které mohou posunout terapeutickou práci se závislostí. Názory na prospěšnost zařazovat maximální možnou zátěž se mění nejen napříc komunitami, vývojem $v$ čase, ale také $z$ pohledu jednotlivých pracovníků. $V$ rámci prípravy probíhá vždy přizpůsobení fyzické a psychické zátěže aktuálnímu složení klientů v komunitě. $v$ př́ípadě vyššího počtu klientů s výraznými zdravotními komplikacemi volí některé komunity, např. Terapeutická komunita Fides, zařazení týmu $B$, který má nižší zátěž než tým A. Programy terapie dobrodružstvím jsou ve všech vybraných komunitách povinnou součástí léčebného programu a klient se nemůže rozhodnout bez závažného odůvodnění programu nezúčastnit.

Průběh programů se liší od zvoleného zaměření fyzických aktivit. Podmínkou je, aby zodpovědní pracovníci tyto aktivity dobře zvládali, měli s nimi zkušenosti a v některých prípadech i instruktorskou licenci tyto aktivity zajištovat. Pravidelnou součástí programů je společné stravování, které je $v$ režii klientů, přesuny na zvolené místo a ve velkém množství programů také zajišš̌ní místa a př́istřešků 
na nocleh. Pracovníci s klienty tráví veškerý čas, kdy probíhá program, a jsou vystaveni stejné fyzické zátěži. $V$ prípadě krizových stavů se situace přednostně řeší na místě. Upřednostňuje se práce s logickými důsledky. Např́iklad pokud se klient na výpravu do hor špatně obleče, a to i po upozornění pracovníkem na nutnost mít teplý oděv, je mu zima. Pokud si vezme nedostatek tekutin, má žízeň. Pokud špatně postaví stan a ten mu v noci spadne, musí jej znovu postavit. Pro detailnější práci se zážitkem jsou používány terapeutické skupiny po návratu do terapeutické komunity.

Tabulka 2

Charakteristika realizovaných programů terapie dobrodružstvím zařazených do výzkumu v roce 2017

\begin{tabular}{lll}
\hline Období & Typ akce & TK (název akce a datum realizace) \\
\hline Zima/jaro 2017 & Běžky & Fides (Běžky chata Olšanka 10.-13. 3.) \\
& & Magdaléna (Běžky 20.-24. 2.) \\
& Němčice (Běžky Šumava 28. 2.-4. 3.) \\
& Fénix (Kola, běžky, kola - Králický Sněžník 13.-15. 3.) \\
& Stanování na sněhu & Fides (Stanování na sněhu 10.-13. 2.) \\
Jaro/léto 2017 & Puták (pěší, cyklo) & Magdaléna (Turistika po Brdech 3.-6. 5.; \\
& & Puták na kolech 22.-26. 6.) \\
& & Advaita (Pěší turistika 20.-23. 5.; \\
& & Cykloturistika 3.-7. 7.) \\
& & Fides (Superpřechod Jeseníků a Rychleb 14.-18. 7.) \\
& Voda & Fides (Řeka Morava 24.-28. 8.) \\
& Horolezectví & White Light I. (Skály - Ostrov 25.-30. 6.) \\
& Jiné (OH, smíšené) & Fides (OH Tomky 22.-26. 6.) \\
& Advaita (Čmelák 27. 8.-1. 9.) \\
Podzim 2017 & Voda & Němčice (Voda Vltava 14.-17. 9.) \\
\hline
\end{tabular}

\section{Metody, sběr dat a jejich analýza}

Použitý výzkumný design je formou experimentu v tom smyslu, že subjekt je v určitém časovém okamžiku vystaven působení nezávislé proměnné (programu terapie dobrodružstvím). Experimentátor tedy záměrně navozuje experimentální podmínky, které nechává na subjekt pưsobit po určitou dobu (doba trvání programu), načež jejich působení opět odnímá. Jako závisle proměnné se sledují vybrané osobnostní charakteristiky, jež jsou měřené pomocí standardizovaných psychologických testů (DOVE, PTS) ve třech časových okamžicích (před, po, 14 dní po programu terapie dobrodružstvím neboli test, retest a follow-up). Výzkum neprobíhá v laboratoři, nýbrž v přirozeném prostředí terapeutické komunity.

Ze statistického pohledu jsou výstupem měření panelová data (druh časové řady), kdy každý subjekt přispívá do datové sady třemi číselnými hodnotami (před, po, 14 dní po), které jsou mezi sebou závislé $v$ tom smyslu, že pocházejí od téhož subjektu. Záměrem je zachytit statisticky významný rozdíl v úrovni testových skórů, který by bylo možno přisoudit působení programu terapie dobrodružstvím, a potvrdit přetrvávající účinek i po 14 dnech. Vhodnou metodou pro danou situaci je dvoufaktorová analýza rozptylu (ANOVA-2), jež je schopna zohlednit variabilitu v datech a odfiltrovat působení náhodných vlivů. Jako jeden faktor (ošetření) zde vystupuje čas administrace testu (před, po, 14 dní po programu), jako druhý faktor (bloky) jednotlivé subjekty.

Pro data, jež nevykazují normálně rozdělené hodnoty, je vhodnější použít neparametrickou obdobu analýzy rozptylu čili konkrétně pro výše uvedenou situaci dvojného třídění Friedmanův neparametrický (pořadový) test. I tento test pracuje $\mathrm{s}$ variabilitou $\mathrm{v}$ datech a je schopen odlišit náhodné fluktuace od systematické změny. (Nicméně výsledky statistického testování byly téměř shodné pro parametrickou i neparametrickou analýzu.) 
Pro sběr dat byly využity dva dotazníky: Profil tělesného sebehodnocení (PTS) (Tomešová, 2005) a Dotazník obecné vlastní efektivity (DOVE) (Křivohlavý, Schwarzer, \& Jeruzalem, 1993).

Multidimenziální Profil tělesného sebehodnocení, profil (PTS) (v originále Physical Self-Perception Profile, PSPP), vytvořil v roce 1989 K. R. Fox jako součást své disertace pod vedením C. Corbina. Dotazník byl autory validizován pro populaci amerických studentů. Do češtiny byl přeložen, upraven a doplněn Tomešovou, která provedla validizaci pod vedením Hoška v roce 2002. Profil se zaměřuje na měření fyzických aspektů self tak, jak se vztahují k sebeúctě (self-esteem). Profil PTS zjišt́uje, jak se lidé hodnotí v pěti oblastech: sportovní kompetence, fyzická kondice, tělesná atraktivita, fyzická síla a tělesná sebeúcta. PTS je sestaven z třiceti položek, jejichž formát je čtyřvýběrový. Každá oblast obsahuje šest tvrzení a umožňuje získat skór v rozmezí šest až dvacet čtyřì.

Dotazník obecné vlastní efektivity (General Self-Efficacy Scale, GSES) je jednodimenzionální dotazník, jehož původní německou verzi vytvořili v roce $1979 \mathrm{M}$. Jerusalem a R. Schwarzer. Původně dvacetipoložková škála byla v roce 1981 upravena a jako desetipoložková škála byla následně přeložena do dvaceti osmi jazyků (Scholz, Gutiérrez-Doña, Sud, \& Schwarzer, 2002; Schwarzer \& Jerusalem, 1995). V současnosti je dotazník $\mathrm{k}$ dispozici ve třiceti třech jazycích. Do češtiny byl přeložen v roce $1993 \mathrm{~J}$. Křivohlavým a je dostupný pod názvem Dotazník obecné vlastní efektivity (DOVE). Dotazník zjištuje míru optimistického sebepojetí, účinnosti vlastního působení a vnímané schopnosti zvládat problémy. Obsahuje deset položek - tvrzení o vnímané vlastní účinnosti (self-efficacy). Tato tvrzení respondenti hodnotí na čtyřstupňové škále ( 1 = naprosto nesouhlasí až 4 = naprosto souhlasí). Hrubý skór tvoří součet jednotlivých položek a pohybuje se v rozmezí 10 až 40 bodů. Vysoký skór předpokládá vysokou míru self-efficacy. Avšak nelze jednoznačně tvrdit, že nízký skór značí jednoznačně nízkou míru self-efficacy a naopak. Průměrný skór se obvykle pohybuje okolo hodnoty 2,9 .

Administrace dotazníků DOVE a PTS probíhala skupinově. $V$ každé terapeutické komunitě byl pověřen pracovník, který administraci a sběr vyplněných dotazníků $v$ př́slušné době zajistil. Sběr dat probíhal ve třech etapách. Abychom co nejvíce předešli zkreslení intervenujícími proměnnými, byly dotazníky zadávány těsně před a těsně po absolvování terapie dobrodružstvím. Po diskuzi s pověřenými pracovníky terapeutických komunit byla administrace dotazníků stanovena na dobu maximálně jeden den před akcí a maximálně do jednoho dne po akci. Těsnější vztah administrace dotazníků a terapie dobrodružstvím nebyl reálný. První etapa sběru dat proběhla před absolvováním programu terapie dobrodružstvím, poté klienti absolvovali několikadenní program, po kterém proběhla druhá etapa sběru dat - po absolvování programu. Po 14 dnech od absolvování programu byl zařazen retest, který může zachytit přetrvávající efekt programu terapie dobrodružstvím. Do statistického zpracování dat byly ponechány pouze celé sady dotazníků, tzn. jeden klient = tři dotazníky (před, po, 14 dní po). Finální počty dotazníků jsou následující: 516 dotazníků DOVE a 498 dotazníků PTS.

Všechny dotazníky byly převedeny do elektronické podoby v programu Microsoft Excel. Statistické testování probíhalo ve 2 fázích. $V$ první fázi byla prostřednictvím Friedmanova testu testována nulová hypotéza HO na hladině významnosti $\alpha=0,05(5 \%)$. V prípadě zamítnutí nulové hypotézy $\mathrm{HO}$ byla realizována druhá fáze: testování rozdílů mezi jednotlivými dvojicemi časů měření (tzv. simultánní testy). Simultánní testy při zamítnutí nulové hypotézy HO byly prováděny na společné hladině významnosti $\alpha=0,05(5 \%)$ s použitím Scheffého a Bonferroniho metody (obě metody dávaly pro naše data shodné závěry).

\section{Výsledky a interpretace}

Dílčí výzkumná otázka č. 1: K jakým statisticky významným změnám dochází v oblasti self-efficacy u klientů TK před, po a 14 dní po absolvování TD?

Do statistického zpracování dat bylo zařazeno 172 dotazníků DOVE. Základní výběrové charakteristiky Ize vyčíst z tabulky 3. Minimální bodový skór dotazníku DOVE je 10 a maximální 40 . $Z$ tabulky je zjevné, 
že došlo ke změnám v hodnotách minimálních bodových skórů. Nejnižší zaznamenaný bodový skór je 10 , a to před absolvováním programu. Po absolvování programu byl zaznamenán minimální bodový skór 16. Po 14 dnech od absolvování programu jsme zaznamenali další změnu, a to minimální bodový skór 19. Maximální bodový skór byl před, těsně po i 14 dní od absolvování programu stejný, a to 40. Průměrná naměřená hodnota se pohybovala v rozpětí 29,40 až 31,09. $Z$ tabulky 3 je zjevné, že těsně po absolvování programu terapie dobrodružstvím i 14 dní od absolvování programu se průměrná hodnota zvýšila.

Tabulka 3

Popisné statistické údaje (DOVE)

\begin{tabular}{lllll}
\hline Čas & N & Min & Max & M (SD) \\
\hline 1 - před absolvováním & 172 & 10 & 40 & $29,40(4,51)$ \\
2 - těsně po absolvování & 172 & 16 & 40 & $30,65(4,83)$ \\
3 - 14 dní od absolvování & 172 & 19 & 40 & $31,09(4,80)$ \\
\hline
\end{tabular}

$H 1_{A}$ - Hodnoty skórů self-efficacy se u klientů terapeutických komunit před, po a 14 dní po absolvování programu terapie dobrodružstvím liší.

Na základě výsledků Friedmanova testu $(p<0,05)$ se nulová hypotéza $H 1_{0}$ zamítá ve prospěch alternativní hypotézy $\mathrm{H} 1_{A}$, přičemž simultánní testy odhalily statisticky významný rozdíl mezi časy administrace dotazníku DOVE (viz Tabulka 4).

Statisticky významný rozdíl byl zaznamenán mezi časy administrace 1 (těsně před programem) vs. 2 (těsně po programu) a mezi časy 1 (těsně před programem) vs. 3 (14 dní od absolvování programu). Mezi časy 2 (těsně po programu) vs. 3 (14 dní od absolvování programu) nebyl prokázán statisticky významný rozdíl.

Tabulka 4

Friedmanův test pro více než dva závislé výběry (DOVE)

\begin{tabular}{ll}
\hline Čas & DOVE $(n=172)$ \\
\hline $\mathrm{k}=3$ (počet měření) & $\mathrm{Z}(\mathrm{p}<0,05)$ \\
Kontrasty: & $\mathrm{p}<0,05$ \\
1 - před absolvováním vs. 2 - těsně po absolvování & $\mathrm{p}<0,05$ \\
1 - před absolvováním vs. 3 - 14 dní od absolvování & $\mathrm{p}>0,05$ \\
2 - těsně po absolvování vs. 3-14 dní od absolvování & \\
\hline
\end{tabular}

Na základě použitých statistických testů, jejichž výsledky pro jednotlivé časy testování jsou uvedeny v tabulce 4, Ize uvést, že self-efficacy neboli míra optimistického sebepojetí, percepce účinnosti vlastního působení a vnímaná schopnost zvládat problémy vykazuje po ukončení akce statisticky významný posun. Po absolvování programu mají klienti terapeutických komunit zvýšený pocit vlastní účinnosti. Vliv programu terapie dobrodružstvím je patrný těsně po akci a přetrvává i po 14 dnech.

Programy terapie dobrodružstvím mají pozitivní vliv na sebedůvěru a sebeúctu a jejich přetrvávající vliv se ukazuje i se čtrnáctidenním odstupem. Na základě použití dotazníku DOVE bylo ověřeno, že klienti zažívají během programů pozitivní autentickou zkušenost. Úspěch se zvládnutím programu jim umocňuje silný pocit vlastní účinnosti. Optimistické sebepojetí posiluje také zástupná pozitivní zkušenost, kterou získávají pozorování ostatních klientů a pracovníků během programu. Programy jsou připravovány tak, aby mohly být klienty úspěšně zvládnuty. Podpora ostatních ve skupině a víra ve schopnosti zvyšuje pravděpodobnost úspěchu, a tím také optimistickou míru sebepojetí klientů.

Následující dílčí výzkumné otázky č. 2-6 se vztahují k tělesnému sebepojetí. Zaměřují se jednak na obecnou tělesnou sebeúctu (TS) a jednak na dílčí prvky tělesné sebeúcty: sportovní kompetence (SPORT), tělesnou atraktivitu (TĚLO), fyzickou sílu (SÍLA) a fyzickou kondici (KOND). V následující tabulce 5 prezentujeme výsledky dotazníku PTS a jeho jednotlivých škál: 
Tabulka 5

Popisné statistické údaje (PTS)

\begin{tabular}{llllllllll}
\hline Tělesná & \multicolumn{3}{c}{ 1-před absolvováním } & \multicolumn{3}{c}{ 2-těsně po absolvování } & \multicolumn{3}{c}{$3-14$ dní od absolvování } \\
sebeúcta & Min & Max & $M(S D)$ & Min & Max & $M(S D)$ & Min & Max & $M(S D)$ \\
\hline SPORT & 12 & 18 & $15,34(1,15)$ & 12 & 19 & $15,36(1,26)$ & 12 & 18 & $15,09(1,01)$ \\
KOND & 12 & 20 & $15,53(1,50)$ & 10 & 19 & $15,74(1,47)$ & 11 & 20 & $15,53(1,39)$ \\
TĚLO & 12 & 18 & $15,33(1,21)$ & 12 & 19 & $15,37(1,25)$ & 11 & 18 & $15,20(1,25)$ \\
SíLA & 11 & 19 & $15,06(1,68)$ & 12 & 19 & $15,36(1,26)$ & 10 & 19 & $14,77(1,68)$ \\
TS & 12 & 18 & $15,34(1,15)$ & 10 & 19 & $15,74(1,47)$ & 12 & 19 & $14,81(1,18)$ \\
\hline
\end{tabular}

Do statistického zpracování dat bylo zařazeno 163 dotazníků PTS (163 před, 163 těsně po a 16314 dní od absolvování programu). Základní výběrové charakteristiky shrnuje tabulka 5 . U škály tělesné sebeúcty stojí za povšimnutí, že při druhém a třetím čase administrace je medián shodný s třetím kvartilem, skóry tedy vykazují poměrně malou variabilitu. Pro připomenutí uvádíme, že každá škála dotazníku PTS umožňuje získat bodový skór v rozmezí 6 až 24 bodů. Z výsledků je zjevné, že změny v jednotlivých škálách jsou nepatrné. Minimální bodový skór se pohyboval v rozmezí 10 až 12 , a to před, těsně po i 14 dní od absolvování programu. Maximální zaznamenaný bodový skór se pohyboval v rozmezí 18 až 20, a to před, těsně po i 14 dní od absolvování programu terapie dobrodružstvím. Průměrná naměřená hodnota se pohybovala v rozmezí 14,77 až 15,74 . Výsledky Friedmanova testu jsou shrnuty v následující tabulce 6 .

Tabulka 6

Friedmanův test pro více než dva závislé výběry (PTS, $n=163)$

\begin{tabular}{llllll}
\hline & & \multicolumn{3}{c}{ Tělesná sebeúcta (PTS) } & \\
Čas & SPORT & KOND & TĚLO & SÍLA & TS \\
\hline $\begin{array}{l}\text { k=3 (počet měření) } \\
\text { Kontrasty: }\end{array}$ & $p=0,014$ & $p=0,010$ & $p=0,525$ & $p=0,080$ & $p=0,770$ \\
$\begin{array}{l}1-\text { před absolvováním vs. 2- těsně } \\
\text { po absolvování }\end{array}$ & $p>0,05$ & $p<0,05$ & - & - & - \\
$\begin{array}{l}1-\text { před absolvováním vs. 3-14 } \\
\text { dní od absolvování }\end{array}$ & $p<0,05$ & $p>0,05$ & - & - & - \\
$\begin{array}{l}2-\text { těsně po absolvování vs. 3-14 } \\
\text { dní od absolvování }\end{array}$ & $p>0,05$ & $p<0,05$ & - & - & - \\
\hline
\end{tabular}

$K$ dílčí výzkumné otázce č. 2: $K$ jakým statisticky významným změnám dochází $v$ doméně Tělesná sebeúcta (TS) u klientů terapeutických komunit před, po a 14 dní po absolvování programu terapie dobrodružstvím?

$\mathrm{H} 2_{\mathrm{A}}$ - Hodnoty skórů domény TS se u klientů terapeutických komunit před, po a 14 dní po absolvování programu terapie dobrodružstvím liší.

Na základě výsledků Friedmanova testu $(p=0,770)$ nelze nulovou hypotézu $H 2_{0}$ zamítnout. Tělesné sebepojetí je subjektivní a elastické - může docházet ke změnám při sociální zkušenosti (Fischer \& Škoda, 2014). Vzhledem k tomu, že realizované programy jsou fyzicky i psychicky náročné, předpokládali jsme, že se hodnoty skórů domény TS budou před, po a 14 dní po absolvování programu lišit. To se však nepotvrdilo. Friedmanův test neprokázal statisticky významný rozdíl mezi časy administrace dotazníku PTS v doméně TS.

Tělesná sebeúcta na doménové úrovni tak, jak ji definuje Tomešová (2005), reflektuje obecné pocity štěstí a spokojenosti, hrdosti, respektu a jistoty $v$ tělesném sebepojetí. Je možné, že změna $v$ této oblasti předpokládá delší časové období, tudiž změny během 14 dnů jsou minimální. Jedná se o jeden 
z možných komentářů, z jakého důvodu celková spokojenost s tělesným Já nemusela po programech terapie dobrodružstvím vykazovat statisticky významné rozdíly.

$K$ dílči výzkumné otázce č. 3: K jakým statisticky významným změnám dochází v subdoméně Sportovní kompetence (SPORT) u klientů TK před, po a 14 dní po absolvování TD? se pojí hypotéza č. 3:

H3 $3_{A}$ - Hodnoty skórů subdomény SPORT se u klientů TK před, po a 14 dní po absolvování TD liší.

Na základě výsledků Friedmanova testu $(p=0,014)$ se nulová hypotéza $\mathrm{H}_{0}$ zamítá ve prospěch alternativní hypotézy $\mathrm{H} 3_{\mathrm{A}}$, přičemž simultánní testy odhalily významný statistický rozdíl mezi časy administrace dotazníku PTS v subdoméně Sportovní kompetence.

Statisticky významný rozdíl byl prokázán pouze mezi časy administrace 1 (těsně před programem) vs. 3 (14 dní od absolvování programu), přičemž došlo k poklesu hodnot skórů. Významnost kontrastu 1 vs. 3 při současné nevýznamnosti kontrastu 1 vs. 2 je zřejmě způsobena nezohledněným faktorem čili některými rušivými vlivy nezahrnutými mezi sledované proměnné.

K dílčí výzkumné otázce č. 4: $\mathrm{K}$ jakým statisticky významným změnám dochází v subdoméně Fyzická kondice (KOND) u klientů terapeutických komunit před, po a 14 dní po absolvování programu terapie dobrodružstvím?

$\mathrm{H} 4_{\mathrm{A}}$ - Hodnoty skórů subdomény KOND se u klientů terapeutických komunit před, po a 14 dní po absolvování programu terapie dobrodružstvím liší.

Na základě výsledků Friedmanova testu $(p=0,0098)$ se nulová hypotéza $H 4_{0}$ zamítá ve prospěch alternativní hypotézy $\mathrm{H} 4_{A}$, přičemž simultánní testy odhalily významný statistický rozdíl mezi časy administrace dotazníku PTS v subdoméně Fyzická kondice.

Statisticky významný rozdíl byl odhalen mezi časem administrace 1 a 2,2 a 3 , tedy těsně před programem terapie dobrodružstvím vs. těsně po programu a těsně po programu a 14 dní od absolvování programu. Vliv programu terapie dobrodružstvím je patrný těsně po ukončení akce, kdy došlo k statisticky významnému zvýšení hodnot skórů. Lze tedy říci, že v oblasti vnímání úrovně fyzické kondice, vytrvalosti a zdatnosti, schopnosti vydržet cvičit, se klienti po absolvování programu cítí statisticky významně lépe. Po 14 dnech od absolvování programu však dochází k poklesu hodnot skórů k původním hodnotám před absolvováním programu terapie dobrodružstvím. Příčinou může být reflexe a zhodnocení akce s odstupem bez přímého ovlivnění emocemi z průběhu akce.

$K$ dílčí výzkumné otázce č. $5: K$ jakým statisticky významným změnám dochází v subdoméně Tělesná atraktivita (TĚLO) u klientů terapeutických komunit před, po a 14 dní po absolvování programu terapie dobrodružstvím?

$\mathrm{H} 5_{\mathrm{A}}$ - Hodnoty skórů subdomény TĚLO se u klientů terapeutických komunit před, po a 14 dní po absolvování programu terapie dobrodružstvím liší.

Na základě výsledku Friedmanova testu $(p=0,525)$ nelze nulovou hypotézu $\mathrm{H} 5_{0}$ zamítnout. Mezi časy administrace dotazníku PTS v subdoméně Tělesná atraktivita nebyl zaznamenán statisticky významný rozdíl.

Vnímaná atraktivita postavy nebo tělesné stavby, schopnost udržet si atraktivní tělo a jistota týkající se vzhledu se absolvováním programu terapie dobrodružstvím nemění. Příčinou může být skutečnost, že na tělesnou atraktivitu a vzhled se tyto akce primárně nezaměřují.

Dílčí výzkumná otázka č. 6 : $\mathrm{K}$ jakým statisticky významným změnám dochází v subdoméně Fyzická síla (SÍLA) u klientů terapeutických komunit před, po a 14 dní po absolvování programu terapie dobrodružstvím?

$H 6_{A}$ - Hodnoty skórů subdomény SílA se u klientů terapeutických komunit před, po a 14 dní po absolvování programu terapie drobrodružstvím liší. 
Na základě výsledku Friedmanova testu $(p=0,080)$ nelze nulovou hypotézu H6 0 zamítnout. Mezi časy administrace dotazníku PTS v subdoméně Fyzická síla nebyl zaznamenán žádný statisticky významný rozdíl.

Subdoména síla by měla ukázat vnímání klientů ve zlepšení schopností rozvrhnout síly. Krizové situace, které v rámci programů terapie dobrodružstvím prožili, jim ale mohou ukazovat také opak. Vnímaná síla, vývoj svalstva a jistota v situacích vyžadujících sílu se absolvováním programu nemění. K možné interpretaci tohoto výsledku nám může být užitečný pohled na to, jak jsou programy připravovány a realizovány. Klient jako jedinec $v$ těchto programech má jen částečně možnost sám pracovat $s$ tím, jak rozvrhnout své síly. Např́klad úsek cesty, který musí klienti zvládnout ujít během stanoveného časového limitu, je dán, stejně tak i některé další dílčí cíle programu, které mají vytvořit záměrně fyzickou i psychickou zátěž. Otázkou je, zda uvažovat nad tím, jak tyto části programu měnit nebo změnit své očekávání od programů terapie dobrodružstvím v této oblasti a mít je zejména v oblastech posilování sebedůvěry a sebeúcty, které se ukazují jako statisticky významné.

\section{Shrnutí a diskuze}

Prostřednictvím výzkumného šetření jsme zjistili odpovědi na šest dílčích výzkumných otázek vztahujících se k hlavní výzkumné otázce, která zní: K jakým statisticky významným změnám dochází $\checkmark$ různých oblastech sebepojetí u klientů terapeutických komunit pro drogově závislé v souvislosti s účastí na aktivitách terapie dobrodružstvím? Získaná data byla statisticky zpracována prostřednictvím Friedmanova testu pro více než dva závislé výběry. Při zamítnutí nulové hypotézy $\mathrm{H}_{0}$ byly následně zjištovány kontrasty mezi dvojicemi časů administrace dotazníků DOVE a PTS a porovnávány hodnoty skórů.

Na základě Friedmanova testu bylo možné zamítnout nulové hypotézy $H 1_{0}, H 3_{0}$ a $H 4_{0}$ ve prospěch alternativních hypotéz $\mathrm{H} 1_{A}, H 3_{A}$ a $H 4_{A}$.

Potvrdil se náš předpoklad, že hodnoty skórů self-efficacy se u klientů terapeutických komunit před, po a 14 dní po absolvování programů terapie dobrodružstvím budou lišit. Simultánní testy odhalily statisticky významný rozdíl mezi časy 1 a 2 (tj. před a po) a mezi časy 1 a 3 (tj. před a 14 dní po), přičemž došlo kzvýšení hodnot skórů. Mezi časy 2 a 3 (tj. po a 14 dní po) nebyl zjištěn statisticky významný rozdíl, během 14 dnů po absolvování programu nedošlo $k$ dalším změnám $v$ oblasti self-efficacy ( $k$ poklesu či zvýšení hodnot skórů). Lze tedy říci, že programy terapie dobrodružstvím pozitivně působí na vnímání vlastní účinnosti, na míru optimistického sebepojetí a vnímanou schopnost zvládat problémy a tyto změny přetrvávají i po 14 dnech od akce.

\author{
Vnímání vlastní účinnosti, \\ míra optimistického \\ sebepojetí a schopnost \\ zvládat problémy se \\ u klientů terapeutických \\ komunit prostřednictvím \\ terapie dobrodružstvím \\ pozitivně mění.
}

Taktéž se potvrdil náš předpoklad, že hodnoty skórů subdomény SPORT a subdomény KOND se budou před, po a 14 dní po absolvování programu terapie dobrodružstvím lišit.

U subdomény SPORT simultánní testy odhalily statisticky významný rozdíl mezi časy 1 a 3 (tj. před a 14 dní po), přičemž došlo k poklesu hodnot skórů této subdomény. Statistická významnost kontrastu 1 a 3 při současné nevýznamnosti kontrastu 1 a 2 jde proti našim očekáváním, pokles hodnot skórů po 14 dnech byl zřejmě způsobem nezohledněným faktorem.

U subdomény KOND je vliv terapie dobrodružstvím patrný těsně po akci, kdy došlo ke zvýšení hodnot skórů této subdomény. Tento vliv však nepřetrvává 14 dní po, nebot' hodnoty skórů se vracejí k původním hodnotám před absolvováním programu. To může být zapříčiněno zhodnocením úrovně fyzické kondice, vytrvalosti a zdatnosti s odstupem bez přímého ovlivnění emocemi z průběhu akce. 
Testované nulové hypotézy $\mathrm{H} 2_{0}, \mathrm{H} 5_{0}$ a $\mathrm{H} 6_{0}$ nebylo možné zamítnout. Friedmanův test neprokázal statisticky významné rozdíly mezi hodnotami skórů před, po a 14 dní po absolvování programu terapie dobrodružstvím v doméně TS (globální tělesná sebeúcta), subdoméně TĚLO (Tělesná atraktivita) a subdoméně SÍLA (Fyzická síla).

Dle textů Gasse et al. (2012) výzkumné studie účinku programů terapie dobrodružstvím vykazují ve značné míře některé chyby. Uvádí tyto: rozsahy respondentů, kteří jsou zařazováni do výzkumu, jsou pro statistická zpracování př́liš malé, ve výzkumu chybí kontrolní skupiny, použité testy nejsou standardizované nebo vykazují nízkou reliabilitu, výzkumníci ve svých studiích nepopisují blí̌e obsah programů terapie dobrodružstvím, které bývají velmi různorodé. $\vee$ návaznosti na tyto texty a analýzu průběžných výsledků bychom rádi $v$ přištím roce zařadili kontrolní skupinu. Budou jimi klienti terapeutických komunit, které nepoužívají programy terapie dobrodružstvím. Podrobněji se také budeme věnovat obsahu jednotlivých programů zařazených do výzkumu. Na základě statistického testování jsme se rozhodli místo testu PTS Tomešové zařadit dva nové testy - Rosenbergovu škálu hodnocení a Test působení zátěže, které nám pomohou zjistit hlouběji některé aspekty účinku programů terapie dobrodružstvím ve vybraných šesti terapeutických komunitách. Budeme pokračovat ve sběru dat před použitím programu terapie dobrodružstvím, po a 14 dní po tak, aby náš získaný soubor dat byl co nejrozsáhlejší a byla jistá možná generalizace zjištění.

Představení dílčích výsledků po prvním roce empirické části výzkumu již ukázal statistickou významnost změny self-efficacy u klientů terapeutických komunit v souvislosti se zařazením programů terapie dobrodružstvím. Jinými slovy míra optimistického sebepojetí, percepce účinnosti vlastního působení a vnímaná schopnost zvládat problémy se ukazuje po ukončení akce u klientů jako statisticky významná. Důležitou informací je také to, že efekt není krátkodobý, ale přetrvává také po 14 dnech po ukončení aktivity. Všechny zkoumané aktivity byly vícedenní, a to jak s plánovanou fyzickou, tak psychickou zátěží pro klienty.

Důležitá je ale také informace, že některé oblasti, ve kterých mohou pracovníci očekávat v obecné míre př́nosy po těchto aktivitách pro klienty, mohou být pouze krátkodobé nebo ne statisticky významné. $\checkmark$ oblasti vytrvalosti a zdatnosti se klienti cítili jen krátkodobě lépe, efekt ale nepřetrval po 14 dnech. V oblasti sportovních kompetencí byla situace oproti očekávání opačná a klienti se cítili po aktivitě statisticky významně hưře. Zajímavostí je například schopnost rozvrhnout si síly měřená subdoménou „Síla“, která statistickou významnost neprokázala.

\subsection{Limity výzkumu}

Realizace tohoto výzkumu vykazuje své limity. $\mathrm{K}$ jednomu z nich patři různorodé pojetí těchto aktivit v jednotlivých terapeutických komunitách. Přestože základní definice byla dodržena u všech zařazených aktivit, míra vnímání a př́pravy „zátěže“ pro klienty pracovníky byla odlišná. Do jedné skupiny se tak dostal týdenní přechod hor se stanováním a nesením veškerých zásob jídla a např. týdenní pobyt na chalupě sice bez vody a elektřiny, ale se zázemím a možností přespání $v$ chráněném prostoru. Také $v$ prrištím roce zařazená kontrolní skupina by mohla upřesnit některé výstupy ze statistického testování.

Gass et al. (2012) ve svém textu používají při popisu, jak vlastně terapie dobrodružstvím funguje, jednu přiléhavou metaforu. Píší, že si máme představit kuchaře, který chce uvařit vynikající a výživnou polévku. Má všechny potřebné ingredience. $V$ našem případě to budou připravení a zkušení terapeutičtí pracovníci, fyzická a psychická zátěž, motivace k akci, malá skupina, netypické prostředí, stres, ale také možnost připravené úkoly zvládnout. Pokud ale kuchař nevyužije své zkušenosti a ingredience jen smíchá, neznamená to, že vytvoří skvělou polévku. Potřebuje znát pravý čas, co kdy přidat, jak dlouho vše vařit, jakým kořením vše dochutit. Některé věci nám zůstanou o fungování terapie dobrodružstvím nadále ukryty. Některé nám ale tento výzkum pomáhá a v př́štím roce bude nadále pomáhat odhalovat. 
Šlachtová, Richterová, \& Müller / Změny sebepojetí klientů terapeutických komunit...

\section{Literatura}

Bandura, A. (1994). Self-efficacy. In V. S. Ramachaudran (Ed.), Encyclopedia of human behavior (pp. 71-81). New York: Academic Press.

Chytilová, L. (2005). Dobrodružné aktivity ve výchově a vzdělávání. Gymnasion: časopis pro zážitkovou pedagogiku, (3), 9-18.

Doležalová, P. (2006). Kvalita života drogově závislých v terapeutických komunitách. Adiktologie, 6(1), $12-25$.

Fischer, S. \& Škoda, J. (2014). Sociální patologie: závažné sociálně patologické jevy, př̌činy, prevence, možnosti řešení. Praha: Grada.

Fleischer, C., Doebler, P., Bürkner, P., \& Holling, H. (2017, červen 6). Adventure therapy effects on selfconcept - A meta-analysis. Dostupné z https://psyarxiv.com/c7y9a

Gass, M. A., Gillis, H. L., \& Russell, K. C. (2012). Adventure therapy: Theory, research, and practice. New York: Brunner-Routledge.

Harper, N., Russell, K., Cooley, R. \& Cupples, J. (2007). Catherine Freer wilderness therapy expeditions: An exploratory case study of adolescent wilderness therapy, family functioning, and the maintenance of change. Child Youth Care Forum, 36, 111-129. https://doi.org./10.1007/s10566007-9035-1

Hartl, P. \& Hartlová, H. (2015). Psychologický slovník. Praha: Portál.

Janoušek, J. (1992). Sociálně kognitivní teorie Alberta Bandury. Československá psychologie, 36(5), 385-398.

Kalina, K. (2008). Terapeutická komunita: obecný model a jeho aplikace v léčbě závislostí. Praha: Grada.

Kalina, K. a kol. (2015). Klinická adiktologie. Praha: Grada.

Kirchner, J. \& Hátlová, B. (2011). Teorie dobrodružné terapie. Praha: European Science and Art Publishing.

Kirchner, J. (2009). Psychologie prožitku a dobrodružství: Pro pedagogiku a psychoterapii. Brno: Computer Press.

Křivohlavý, J., Schwarzer, R. \& Jerusalem, M. (1993). Czech adaptation of the General Self-Efficacy Scale. Československá psychologie, 52(1), 1-19.

Lebeda, P. (2006). Teorie komfortní zóny. Gymnasion: Časopis pro zážitkovou pedagogiku, 3(5), 146147.

Lewis, S. (2013). Examining changes in substance use and conduct problems among treatment-seeking adolescents. Child and Adolescent Mental Health, 18(1), 33-38. https://doi.org/10.1111/j.14753588.2012.00657.x

Mutz, M. \& Müller, J. (2016). Mental health benefits of outdoor adventures: Results from two pilot studies. Journal of adolescence, 49, 105-114. https://doi.org/10.1016/j.adolescence.2016.03.009

Radimecký, J. (2006). Očekávání pracovníků terapeutických komunit vs. proces změny chování klientů. Adiktologie, 6(1), 43-53.

Rataj, M. (2007). Zátěžové programy. In P. Nevšímal (ed.), Terapeutická komunita pro drogově závislé II: Česká praxe. Praha: Středočeský kraj.

Rečková, J. (2010). Sebepojetív léčbě závislostí (Diplomová práce). Zlín: Univerzita Tomáše Bati ve Zlíně. Dostupné z http://digilib.k.utb.cz/bitstream/handle/10563/13212/re\%C4\%8Dkov\%C3\%A1_2010_dp.pdf 
Šlachtová, Richterová, \& Müller / Změny sebepojetí klientů terapeutických komunit...

Richterová, B., Štenclová, V. \& Červenková, K. (2017). Adventure Therapy in therapeutic community Fides - Quantitative Outcomes of the research. AD ALTA: Journal of Interdisciplinary Research, 2(11), 181-184.

Richterová, B., Takács, O., Pindáková, J., Slivková, M., Tešnarová, D., Polášková, D. \& Fešarová, V. (2015). Zátěžové aktivity a léčba drogově závislých. GRANT Journal, 4(1), 92-97.

Romaněnková, E. (2012). Využití terapie dobrodružstvím v terapeutických komunitách v České republice. (Bakalářská práce). Praha: Univerzita Karlova v Praze. Dostupné z https://is.cuni.cz/webapps/zzp/detail/120219/?lang=en

Scholz, U., Gutiérrez-Doña, B., Sud, S. \& Schwarzer, R. (2002). Is general self-efficacy a universal construct? Psychometric findings from 25 countries. European Journal of Psychological Assessment, 18(3), 242-251. https://doi.org/10.1027//1015-5759.18.3.242

Schwarzer, R. \& Jerusalem, M. (1995). Generalized Self-Efficacy scale. In J. Weinman, S. Wright, \& M. Johnston, Measures in health psychology: A user's portfolio. Causal and control beliefs (pp. 3537). Windsor, UK: NFER-NELSON.

Seznam a definice výkonů drogových služeb. (2017, květen 20). drogy - info. Dostupné z https://www.drogy-info.cz/publikace/navykove-latky/metodika/seznam-a-definice-vykonudrogovych-sluzeb/.

Srovnal, M. (2018). Výzkumy terapie dobrodružstvím - Přehledová studie. (Diplomová práce). Ostrava: OSU PDF.

Tomešová, E. (2005). Mezikulturní prevod a validizace Profilu tělesného sebehodnocení. (Disertační práce). Praha: FTVS UK. 